\title{
A Comparison of Apgar Scores and Changes in the Neonates of Gestational Diabetes Mellitus Patients Treated with Metformin versus Glyburide: A Systematic Review
}

\author{
Sumanta Saha ${ }^{a}$ Sujata Saha ${ }^{b}$ \\ ${ }^{a}$ National Institute for Research in Tuberculosis, Chennai, India; ${ }^{b}$ Mankar College, Mankar, India
}

\section{Keywords}

Metformin · Glyburide · Gestational diabetes mellitus ·

Apgar score $\cdot$ Infant $\cdot$ Newborn

\begin{abstract}
Aims: This study aims to compare the Apgar scores (at different time points after birth) and their changes between the newborns of gestational diabetes mellitus (GDM) patients treated with metformin and glyburide, respectively. Methods: Electronic databases were searched for randomized controlled trials that compared these outcomes between the above-depicted intervention groups. The data about the study design, the population characteristics, the interventions compared, and the outcomes of interest were extracted from the eligible trials. Then, these trials were critically appraised by the Cochrane tool. After that, the effect of the tested interventions on the respective outcomes of interest was reported narratively. Results: The literature search produced 4 single-center trials sourcing data from about 538 participants in the USA, Brazil, and Israel. The risk of detection and performance bias was unclear in the respective trials. The trials primarily reported about the Apgar scores at 1 and 5 min
\end{abstract}

karger@karger.com www.karger.com/dde

Karger $\stackrel{\text { ' }}{5}$

BOPEN ACCESS
(C) 2020 The Author(s)

Published by S. Karger AG, Basel

This article is licensed under the Creative Commons AttributionNonCommercial-NoDerivatives 4.0 International License (CC BYNC-ND) (http://www.karger.com/Services/OpenAccessLicense) Usage and distribution for commercial purposes as well as any distribution of modified material requires written permission. after birth. These scores were not different between glyburide- and metformin-treated GDM patients in any trial. No trial reported the Apgar score at 10 min after birth or the changes in Apgar score between 1, 5, or 10 min after birth. Conclusion: In all trials, the Apgar scores at 1 and 5 min after birth did not vary between the newborns of GDM mothers treated with metformin and glyburide, respectively.

(C) 2020 The Author(s)

Published by S. Karger AG, Basel

\section{Introduction}

Apgar score is the vitality index of a newborn [1]. Almost every newborn receives an Apgar score at $1 \mathrm{~min}, 5$ $\mathrm{min}$, and $10 \mathrm{~min}$ after birth [1]. Following birth, this scoring system is a quick way of assessing a neonate [2]. It is often performed by a nurse, midwife, or physician [2]. The scoring is based on skin color, heart rate, respiratory effort, muscle tone, and reflex irritability $[1,2]$. Each of these measured components is scored as zero, 1, or 2 [2]. An overall score of 7-10 is considered "normal" $[1,2]$.

Apgar scores at different time points (1, 5, and $10 \mathrm{~min}$ after birth) have both short- and long-term health impli- 
cations. Short-term consequences like an excess need of cardiopulmonary resuscitation, intubation, positive pressure ventilation, and catheterization of the umbilical vessel are primarily seen in preterm babies with poor Apgar scores [3]. Term-born babies with a low Apgar score (03 ) are more prone to the risk of neonatal death (by almost 80 -fold) than a normal score at 5 min after birth [4]. Regarding the long-term risks, a low Apgar score at $5 \mathrm{~min}$ and/or at $10 \mathrm{~min}$ increases the risk of cerebral palsy (CP) $[1,2,5]$, epilepsy [1], and autism spectrum disorder [6]. As the Apgar score at $1 \mathrm{~min}$ and $5 \mathrm{~min}$ after birth decreases, the childhood developmental vulnerability and special needs (at 5 years of age) tend to increase [7]. Changes in Apgar scores between 2 of the time points also increase certain long-term risks. For instance, small changes in the normal Apgar score from 5 to 10 min heightens the risk of CP and epilepsy [1]. The long-term risk of epilepsy was studied in a large population-based cohort study in Denmark on $>1$ million live newborns who were followed up for $17,953,700$ person-years [8]. Later in childhood, 16,455 of these newborns were diagnosed with epilepsy (i.e., an average incidence rate of 91.7 cases/100,000 person-years) [8]. Their incidence rate ratios of developing epilepsy were higher when a low 1-min Apgar score improved at 5 min of life than those with a normal Apgar score (7-10) at both time points [8].

Given these short- and long-term implications of Apgar scores and their changes, it is important to study how they vary between the neonates of metformin- and glyburide-treated gestational diabetes mellitus (GDM) patients. GDM is a carbohydrate intolerance that develops during pregnancy and requires pharmacotherapeutic intervention when hyperglycemia cannot be controlled with lifestyle and dietary interventions alone [9]. In these patients, metformin and glyburide are 2 oral hypoglycemic agents used as reasonable alternatives to insulin due to their ease of administration, patient satisfaction, and compliance; however, due to their potential for crossing the placenta and lack of adequate long-term neonatal safety data, it is imperative to study their effects on newborns of GDM mothers treated with these drugs [9]. Existing systematic reviews and meta-analyses have primarily compared the safety profile of the offspring of metformin- and glyburide-treated GDM patients with that of the newborns of insulin-treated GDM mothers, respectively $[10,11]$. Therefore, how the Apgar scores (and their changes) at (and between) different time points after birth differ between newborns of metformin- and glyburide-treated GDM mothers remains underexplored. This study aims to review this difference systematically.

\section{Methods}

The following points comprised the inclusion criteria: 1 . Study design: a parallel-arm randomized controlled trial (RCT) of any duration. 2. Population: pregnant females of any age diagnosed with GDM during pregnancy. A diagnosis of GDM was accepted as per the trialists. 3. Intervention: the trial had to have compared between metformin and glyburide treatment in GDM patients who failed to respond to non-pharmacological interventions like diet and exercise. The dosage of these medications and the treatment duration was accepted as per the trialists. 4. Outcome: for inclusion in this review, a trial must have reported Apgar scores at $\geq 1$ of the following time points after birth: $1 \mathrm{~min}, 5 \mathrm{~min}$, and 10 min, with or without the changes between these time points. These scores could be reported as categorical data and/or continuous data. Trials were excluded if they included participants with any other form of diabetes, i.e., type 1 or type 2 . A pre-published protocol does not exist for this review.

We searched various electronic databases (PubMed, Embase, and Scopus) without any restrictions regarding date or language to identify trials meeting the above-depicted eligibility criteria. The last date of this search was 9 October 2019. The titles and abstracts of published trials were searched using the following search terms: "gestational diabetes" OR "GDM" AND "metformin" AND "glibenclamide" OR "glyburide" AND "clinical trial” OR "randomized" OR "randomized” OR “controlled." In PubMed and Embase, we used filters to narrow down the search results to clinical trials. Besides this, we manually searched an internet-based search engine ("Google") and the bibliography of reviewed articles.

Next, after excluding the duplicates, the titles and abstracts of the searched papers were read and subsequently sorted for full-text reading. A paper was read in full text when it seemed to match the eligibility criteria of our review or when a decision of inclusion or exclusion was not possible by reading the titles and abstracts only. After the recruitment of eligible trials, data regarding study design, participant characteristics, interventions, and the outcome of interest were extracted. Next, using the Cochrane tool, we assessed the risk of bias of the respective trials [12]. Each trial was evaluated for selection bias, detection bias, performance bias, attrition bias, reporting bias, and others, and depending on the risk, each was labeled as low, high, or unclear (when it could not be labeled as high or low) [12]. We selected the eligible trials, performed the risk-of-bias assessment, and extracted data from the included trials, independently of one another. When our findings did not match, a discourse followed for a resolution, and it was not necessary to obtain the opinion of a third party. None of the reviewed trials' authors were contacted.

Due to the paucity of trials and the non-comparable nature of the data, a meta-analytic comparison between the interventions was not feasible. Henceforth, qualitative reporting was used to report the findings of the respective trials.

\section{Results}

Cumulatively, 75 search results were obtained. After excluding the duplicates, the titles and abstracts of $61 \mathrm{pa}-$ pers were read. Eight studies required a full-text reading.
Saha/Saha 
Fig. 1. PRISMA flow diagram (adapted from Moher et al. [18]).

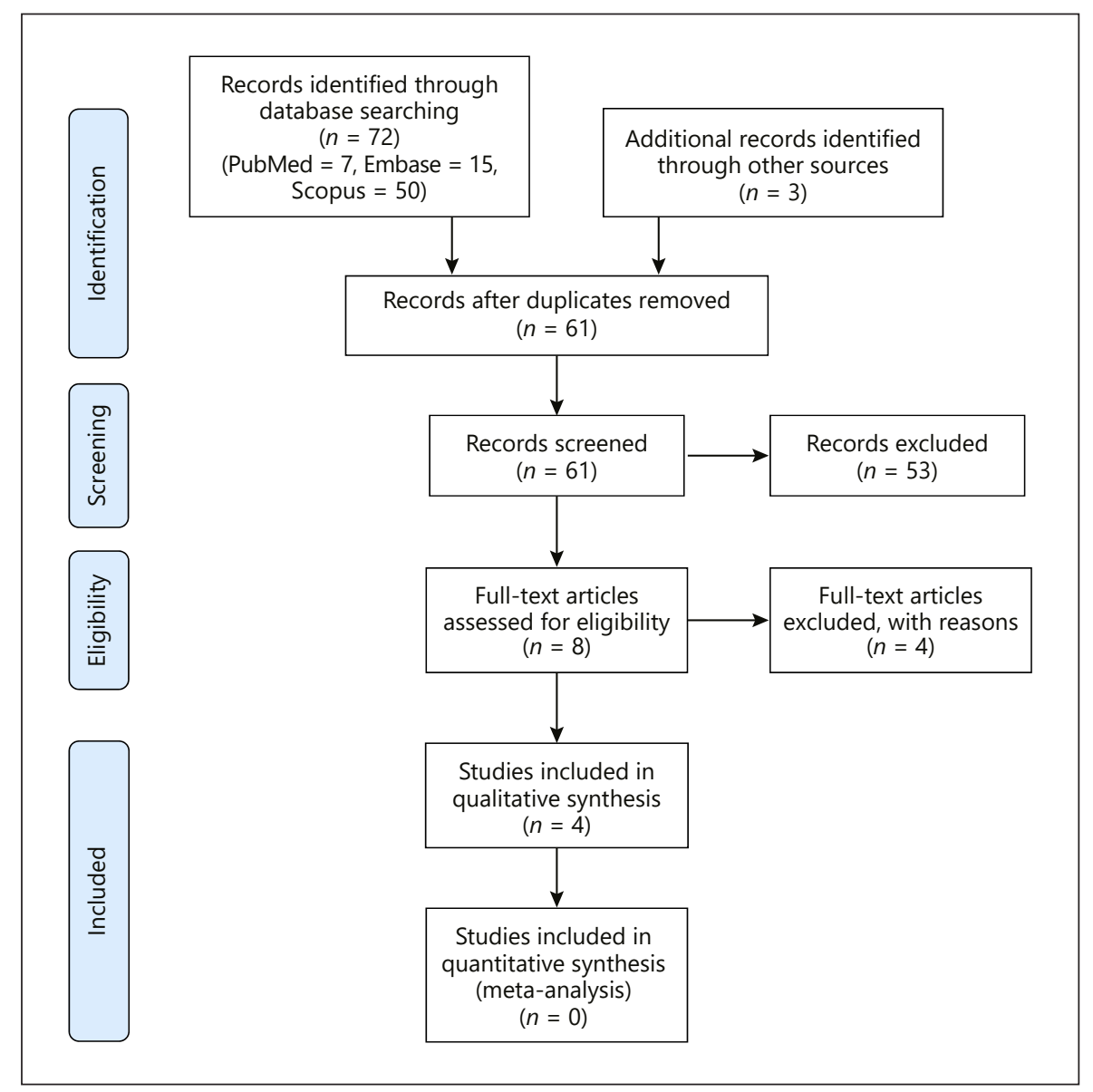

Finally, 4 single-center trials published between 2010 and 2017 (matching the aforementioned eligibility criteria) were reviewed (Fig. 1). [13-16] Overall, about 538 participants (from Brazil [14, 15], the USA [16], and Israel [13]) with an average age of 30-33 years were recruited. The gestational age of the participants was between 11 and 33 weeks. Before starting pharmacotherapy, the GDM patients had nutritional and exercise interventions in 3 of the trials [14-16] and dietary therapy in 1 trial [13]. The salient features of the trials are depicted in Table 1.

Regarding the risk of bias, the risk of performance bias and detection bias was unclear across all trials as it was not clear if the outcome assessors were also the interventionists and if they were blinded or not (Table 2) [13-16]. Clear blinding of the outcome assessor is vital since Apgar score is somewhat subjective and prone to inter-rater variability [2]. For the rest of the components, the risk of bias was low in all 4 trials.

The Apgar score-related findings were reported categorically in 2 trials $[13,16]$, in a continuous form in $1[15]$, and as a combination of categorical and continuous data in 1 [14]. 3 trials contrasted the 1-min and 5-min Apgar score between the metformin and glyburide treated arms, respectively [13-15]. Whereas, the remaining trial compared the 5-min Apgar scores only [16]. None of the trials compared the 10-min Apgar scores or the changes in Apgar score between the various time points [13-16].

The 1-min Apgar score did not vary statistically, irrespective of whether it was dealt with as categorical or continuous data [13-15]. In Nachum et al. [13], at $1 \mathrm{~min}$ after birth, the proportion of newborns with an Apgar score of $<7$ was identical in the metformin-treated $(2 / 51)$ and glyburide-treated (2/53) groups. The mean 1-min Apgar score in the glyburide and metformin groups in Silva et al. [15] was $8(\mathrm{SD}=1)$ and $8.1(\mathrm{SD}=0.9)$, respectively; in the other study of Silva et al., it was 8.08 (SD = $1.07)$ and $8.17(\mathrm{SD}=1.18)$, respectively [14]. Mean 5-min Apgar score was also not statistically significantly different between the treatment groups in these 2 studies $(p=$ 0.24 [15] and $p=0.05$ [14]). Nachum et al. [13] reported 
Table 1. Salient features of the 4 trials reviewed

\begin{tabular}{|c|c|c|c|c|}
\hline $\begin{array}{l}\text { First author } \\
\text { [ref.], year }\end{array}$ & Study design & Participants & Interventions & Reported outcomes \\
\hline $\begin{array}{l}\text { Moore } \\
{[16], 2010}\end{array}$ & $\begin{array}{l}\text { Randomized controlled trial } \\
\text { Parallel-arm } \\
\text { Open-label } \\
\text { Single-blind } \\
\text { Single-center } \\
\text { Funding information: provided } \\
\text { Ethics clearance: obtained } \\
\text { Trial ID: NCT00965991 }\end{array}$ & $\begin{array}{l}\text { Diagnosis: GDM } \\
\text { Diagnostic criteria: Carpenter and Coustan } \\
\text { guidelines } \\
\text { Gestational age at recruitment: } 11-33 \\
\text { weeks } \\
\text { Randomized ( } n=149) \\
\text { Eligible age of participants: } \geq 13 \text { years } \\
\text { Mean age: } 30 \text { years } \\
\text { Consent: obtained } \\
\text { Country: USA }\end{array}$ & $\begin{array}{l}\text { All participants received } \\
\text { dietary and exercise counselling } \\
\text { and dietary therapy } \\
\text { Glyburide }(n=74): 2.5 \mathrm{mg} 2 \times \\
\text { daily initially, increased to a } \\
\text { maximum of } 20 \mathrm{mg} / \text { day } \\
\text { Metformin }(n=75): 500 \mathrm{mg} / \\
\text { day initially, increased to a } \\
\text { maximum of } 2 \text { g/day }\end{array}$ & $\begin{array}{l}5 \text {-min Apgar score } \\
\text { of }<7\end{array}$ \\
\hline $\begin{array}{l}\text { Nachum } \\
{[13], 2017}\end{array}$ & $\begin{array}{l}\text { Randomized controlled trial } \\
\text { Parallel-arm } \\
\text { Open-label } \\
\text { Single-center } \\
\text { Funding information: provided } \\
\text { Ethics clearance: obtained } \\
\text { Trial ID: NCT01563120 }\end{array}$ & $\begin{array}{l}\text { Diagnosis: GDM } \\
\text { Diagnostic criteria: Carpenter and Coustan } \\
\text { or } 1979 \text { National Diabetes Data Group } \\
\text { criteria } \\
\text { Gestational age at recruitment: } 13-33 \\
\text { weeks } \\
\text { Gestational age at randomization: } 1 \text { week } \\
\text { Randomized ( } n=108) \\
\text { Eligible age of participants: } 18-45 \text { years } \\
\text { Mean age: } 33 \text { years } \\
\text { Consent: obtained } \\
\text { Country: Israel }\end{array}$ & $\begin{array}{l}\text { Glyburide }(n=53): 2.5-20 \mathrm{mg} / \\
\text { day } \\
\text { Metformin }(n=51): 850-2,550 \\
\text { mg/day }\end{array}$ & $\begin{array}{l}\text { 1-min Apgar score } \\
\text { of }<7 \\
5 \text {-min Apgar score } \\
\text { of }<7\end{array}$ \\
\hline $\begin{array}{l}\text { Silva [15], } \\
2010\end{array}$ & $\begin{array}{l}\text { Randomized controlled trial } \\
\text { Parallel-arm } \\
\text { Open-label } \\
\text { Single-center } \\
\text { Funding information: not } \\
\text { available (study medications } \\
\text { were provided free of charge by } \\
\text { the public health service) } \\
\text { Ethics clearance: obtained } \\
\text { Trial ID: not available }\end{array}$ & $\begin{array}{l}\text { Diagnosis: GDM } \\
\text { Diagnostic criteria: World Health } \\
\text { Organization criteria } \\
\text { Gestational age at recruitment: } 11-33 \\
\text { weeks } \\
\text { Randomized }(n=81) \\
\text { Eligible age of participants: } \geq 18 \text { years } \\
\text { Mean age: } 32 \text { years } \\
\text { Consent: obtained } \\
\text { Country: Brazil }\end{array}$ & $\begin{array}{l}\text { Glyburide }(n=40): 2.5 \mathrm{mg} 2 \times \\
\text { daily to a maximum of } 20 \mathrm{mg} / \\
\text { day based on the requirement } \\
\text { Metformin }(n=32): 500 \mathrm{mg} 2 \times \\
\text { daily to a maximum of } 2,500 \\
\text { mg/day based on the } \\
\text { requirement }\end{array}$ & $\begin{array}{l}\text { 1-min Apgar score } \\
\text { of }<7 \\
5 \text {-min Apgar score } \\
\text { of }<7\end{array}$ \\
\hline
\end{tabular}

several neonates with a 5-min Apgar score of $<7$; however, it was not statistically significantly different between the compared groups $(p=1.00)$. In Moore et al. [16], there were no neonates with a 5-min Apgar score of $<7$.

In 2 trials, the precise effect of the interventions on the Apgar scores were uncertain. In Silva et al. [14], the time (in minutes) after birth, when the (statistically not significant) $<7$ Apgar score was compared among the intervention groups, remains unclear. In Nachum et al. [13], the Apgar scores of the neonates of glyburide-treated GDM patients who experienced hypoglycemia may have been masked by the effect of metformin, as metformin was also administered to them at certain times of the day. 
Table 2. Risk-of-bias assessment

\begin{tabular}{|c|c|c|c|c|c|c|c|}
\hline $\begin{array}{l}\text { First author } \\
\text { [ref.], year }\end{array}$ & $\begin{array}{l}\text { Random } \\
\text { sequence } \\
\text { generation } \\
\text { (selection } \\
\text { bias) }\end{array}$ & $\begin{array}{l}\text { Allocation } \\
\text { concealment } \\
\text { (selection } \\
\text { bias) }\end{array}$ & $\begin{array}{l}\text { Blinding of participants and } \\
\text { personnel } \\
\text { (performance bias) } \\
\text { All outcomes }\end{array}$ & $\begin{array}{l}\text { Blinding of } \\
\text { outcome } \\
\text { assessment } \\
\text { (detection bias) } \\
\text { All outcomes }\end{array}$ & $\begin{array}{l}\text { Incomplete outcome } \\
\text { data (attrition bias) } \\
\text { All outcomes }\end{array}$ & $\begin{array}{l}\text { Selective } \\
\text { reporting } \\
\text { (reporting } \\
\text { bias) }\end{array}$ & $\begin{array}{l}\text { Other } \\
\text { bias }\end{array}$ \\
\hline $\begin{array}{l}\text { Moore } \\
{[16], 2010}\end{array}$ & Low & Low & $\begin{array}{l}\text { Unclear } \\
\text { Comment: it is unlikely that the open- } \\
\text { label nature of the study affected the } \\
\text { Apgar scores; however, it is not clear } \\
\text { whether the study personnel and } \\
\text { outcome assessors were the same } \\
\text { individuals, so the risk of bias remains } \\
\text { unclear }\end{array}$ & $\begin{array}{l}\text { Unclear } \\
\text { Comment: blinding } \\
\text { of Apgar score } \\
\text { assessor/s was not } \\
\text { clear }\end{array}$ & $\begin{array}{l}\text { Low } \\
\text { Comment: outcome } \\
\text { data available for all } \\
\text { participants } \\
\text { randomized to the } \\
\text { intervention groups }\end{array}$ & Low & Low \\
\hline $\begin{array}{l}\text { Nachum } \\
{[13], 2017}\end{array}$ & Low & Low & $\begin{array}{l}\text { Unclear } \\
\text { Comment: it is unlikely that the open- } \\
\text { label nature of the study affected the } \\
\text { Apgar scores; however, it is not clear } \\
\text { whether the study personnel and } \\
\text { outcome assessors were the same } \\
\text { individuals, so the risk of bias remains } \\
\text { unclear }\end{array}$ & $\begin{array}{l}\text { Unclear } \\
\text { Comment: blinding } \\
\text { of Apgar score } \\
\text { assessor/s was not } \\
\text { clear }\end{array}$ & $\begin{array}{l}\text { Low } \\
\text { Comment: outcome } \\
\text { data available for all } \\
\text { participants } \\
\text { randomized to the } \\
\text { intervention groups }\end{array}$ & Low & Low \\
\hline $\begin{array}{l}\text { Silva } \\
{[15], 2010}\end{array}$ & Low & Low & $\begin{array}{l}\text { Unclear } \\
\text { Comment: it is unlikely that the open- } \\
\text { label nature of the study affected the } \\
\text { Apgar scores; however, it is not clear } \\
\text { whether the study personnel and } \\
\text { outcome assessors were the same } \\
\text { individuals, so the risk of bias remains } \\
\text { unclear }\end{array}$ & $\begin{array}{l}\text { Unclear } \\
\text { Comment: blinding } \\
\text { of Apgar score } \\
\text { assessor/s was not } \\
\text { clear }\end{array}$ & $\begin{array}{l}\text { Low } \\
\text { Comment: outcome } \\
\text { data not reported for } \\
\text { very few participants } \\
(n=8)\end{array}$ & Low & Low \\
\hline $\begin{array}{l}\text { Silva } \\
{[14], 2012}\end{array}$ & Low & Low & $\begin{array}{l}\text { Unclear } \\
\text { Comment: it is unlikely that the open- } \\
\text { label nature of the study affected the } \\
\text { Apgar scores; however, it is not clear } \\
\text { whether the study personnel and } \\
\text { outcome assessors were the same } \\
\text { individuals, so the risk of bias remains } \\
\text { unclear }\end{array}$ & $\begin{array}{l}\text { Unclear } \\
\text { Comment: blinding } \\
\text { of Apgar score } \\
\text { assessor/s was not } \\
\text { clear }\end{array}$ & $\begin{array}{l}\text { Low } \\
\text { Comment: outcome } \\
\text { data not reported for } \\
\text { very few participants } \\
(n=4)\end{array}$ & Low & Low \\
\hline
\end{tabular}

\section{Discussion}

To summarize, we reviewed 4 single-center RCTs, published between 2010 and 2017, that sourced data on about 538 GDM patients. Overall, the trials had a low risk of bias, with only the risk of performance bias and detection bias being unclear. Between the compared intervention groups, the mean 1-min and 5-min Apgar scores [14, $15]$ and the number of neonates with an Apgar score of $<7$ did not vary $[13,16]$.

Then, to compare our findings with the existing literature, we found only 1 review that addressed the context partially. It compared the 5-min Apgar scores of $<7$ in the newborns of metformin- and glyburide-treated GDM mothers and found only 1 relevant trial with no events in either of the treatment groups [17].

Apgar Score in Neonates of Metforminand Glyburide-Treated GDM Patients
Neonatologists, pediatricians, pediatric nurses, and obstetricians may find our review useful for gaining some insights into the context, based on the currently available evidence. The strengths of this review are that it is reasonably comprehensive and rigorous, as its database search was not restricted to any specific date or language, and it included only RCTs, i.e., the highest level of epidemiological evidence. Moreover, the concept of this paper appears to be novel since we could not find any other study reviewing this context in this detail.

Finally, there were a few limitations to this review. At the study level, the single-center design of all of the trials plausibly undermines the external validity of the findings. At the outcome level, the availability of fewer trials, together with the inconsistent manner of reporting the Apgar scores, did not allow for a quantitative 
comparison of the outcome by meta-analysis. The trials also had an unclear risk of performance bias and detection bias.

\section{Conclusion}

The Apgar score at $1 \mathrm{~min}$ and $5 \mathrm{~min}$ after birth did not vary between the neonates of the glyburide- and metformin-treated GDM mothers in any of the trials. In this milieu, there is a substantial lack of evidence about the 10-min Apgar score and the changes in Apgar score between various time points after birth.

\section{Disclosure Statement}

This work has been done by the authors independently and is not related to their affiliated institutions. There were no conflicts of interest.

\section{Funding Sources}

No funding was received for this study.

\section{Author Contributions}

Sumanta Saha contributed to the conception, design, risk-ofbias assessment, and writing of the manuscript. Sujata Saha contributed to the risk-of-bias assessment and the proof-reading of the manuscript.

\section{References}

1 Persson M, Razaz N, Tedroff K, Joseph KS, Cnattingius S. Five and 10 minute Apgar scores and risks of cerebral palsy and epilepsy: population based cohort study in Sweden. BMJ. 2018 Feb;360:k207.

2 Simon LV, Hashmi MF, Bragg BN. APGAR Score. StatPearls. [Internet]. Treasure Island (FL): StatPearls Publishing; 2020.

3 Weinberger B, Anwar M, Hegyi T, Hiatt M, Koons A, Paneth N. Antecedents and neonatal consequences of low Apgar scores in preterm newborns: a population study. Arch Pediatr Adolesc Med. 2000 Mar;154(3):294300.

4 Moster D, Lie RT, Irgens LM, Bjerkedal T, Markestad T. The association of Apgar score with subsequent death and cerebral palsy: A population-based study in term infants. J Pediatr. 2001 Jun;138(6):798-803.

5 Committee on Obstetric Practice American Academy of Pediatrics - Committee on Fetus and Newborn. Committee Opinion No. 644: The Apgar Score. Obstet Gynecol. 2015 Oct; 126(4):e52-5.

6 Modabbernia A, Sandin S, Gross R, Leonard H, Gissler M, Parner ET, et al. Apgar score and risk of autism. Eur J Epidemiol. 2019 Feb; 34(2):105-14.
7 Razaz N, Cnattingius S, Persson M, Tedroff K, Lisonkova S, Joseph KS. One-minute and five-minute Apgar scores and child developmental health at 5 years of age: a populationbased cohort study in British Columbia, Canada. BMJ Open. 2019 May;9(5):e027655.

8 Sun Y, Vestergaard M, Pedersen CB, Christensen J, Olsen J. Apgar scores and long-term risk of epilepsy. Epidemiology. 2006 May; 17(3):296-301.

9 Committee on Practice Bulletins-Obstetrics. ACOG Practice Bulletin No. 190: Gestational Diabetes Mellitus. Obstet Gynecol. 2018 Feb; 131(2):e49-64.

10 Zeng YC, Li MJ, Chen Y, Jiang L, Wang SM, Mo XL, et al. The use of glyburide in the management of gestational diabetes mellitus: a meta-analysis. Adv Med Sci. 2014 Mar;59(1): 95-101.

11 Tarry-Adkins JL, Aiken CE, Ozanne SE. Neonatal, infant, and childhood growth following metformin versus insulin treatment for gestational diabetes: A systematic review and meta-analysis. PLoS Med. 2019;16:e1002848.

12 Higgins J, Churchill R, Chandler J, Cumpston $M$, editors. [Internet] Cochrane Handbook for Systematic Reviews of Interventions version 5.2.0 (updated June 2017). Available from: https://training.cochrane.org/handbook/archive/v5.2
13 Nachum Z, Zafran N, Salim R, Hissin N, Hasanein J, Gam Ze Letova Y, et al. Glyburide versus Metformin and Their Combination for the Treatment of Gestational Diabetes Mellitus: A Randomized Controlled Study. Diabetes Care. 2017 Mar;40(3):332-7.

14 Silva JC, Fachin DR, Coral ML, Bertini AM. Perinatal impact of the use of metformin and glyburide for the treatment of gestational diabetes mellitus. J Perinat Med. 2012 Jan;40(3): 225-8.

15 Silva JC, Pacheco C, Bizato J, de Souza BV, Ribeiro TE, Bertini AM. Metformin compared with glyburide for the management of gestational diabetes. Int J Gynaecol Obstet. 2010 Oct;111(1):37-40.

16 Moore LE, Clokey D, Rappaport VJ, Curet LB. Metformin compared with glyburide in gestational diabetes: a randomized controlled trial. Obstet Gynecol. 2010 Jan;115(1):55-9.

17 Brown J, Martis R, Hughes B, Rowan J, Crowther CA. Oral anti-diabetic pharmacological therapies for the treatment of women with gestational diabetes. Cochrane Database Syst Rev. 2017 Jan;1:CD011967.

18 Moher D, Liberati A, Tetzlaff J, Altman DG; PRISMA Group. Preferred reporting items for systematic reviews and meta-analyses: the PRISMA statement. BMJ. 2009 Jul;339:b2535. 